\title{
Upacara Adat Ngaruwat Bumi sebagai Kajian Nilai Budaya Masyarakat Adat Banceuy dalam Melestarikan Lingkungan
}

\author{
Amelia Haryantia, ${ }^{a *}$ \\ aProgram Studi Pendidikan Pancasila dan Kewarganegaraan, \\ Fakultas Keguruan dan Ilmu Pendidikan, Universitas Pamulang, Tangerang Selatan \\ ${ }^{1}$ dosen00811@unpam.ac.id \\ *korespondensi penulis
}

Naskah diterima: 23-08-18, direvisi: 20-09-18, disetujui: 30-09-18

DOI: http://dx.doi.org/10.32493/jpkn.v5i2.y2018.p151-166

\begin{abstract}
Abstrak
Upacara adat ngaruwat bumi adalah tradisi yang rutin dilaksanakan oleh masyarakat adat di kampung Banceuy Kabupeten Subang Jawa Barat sebagai bentuk dan upaya dalam melestarikan lingkungan. Tujuan penelitian ini adalah untuk mengetahui hubungan nilainilai budaya adat dalam melestarikan lingkungan yang dilakukan masyarakat adat Banceuy. Penelitian ini menggunakan metode penelitian yang bersifat deskripsi atau menggambarkan secara tepat sifat-sifat suatu gejala sosial, baik individu-individu, kelompok-kelompok, dan keadaan sosial tertentu. Hasil penelitian menunjukan bahwa dengan melaksanakan upacara dan ritual adat ngaruwat bumi, masyarakat adat Banceuy dapat mempertahankan dan melestarikan lingkungannya. Untuk itu dibutuhkan usaha dan dukungan dari semua lapisan masyarakat dalam mempertahankan keberadaan masyarakat adat ini agar keberadaannya tetap terlindungi dari derasnya arus modernisasi yang terus menerus berkembang.
\end{abstract}

Kata-kata kunci: upacara adat; pelestarian lingkungan; nilai budaya adat

\section{Abstract}

The Ngaruwat Bumi Ceremony is a tradition routinely carried out by indigenous people in the Banceuy Sub-District Subang, West Java, as a form and effort to preserve the environment. The purpose of this study was to determine the relationship of traditional cultural values in preserving the environment carried out by the Banceuy indigenous people. This study uses research methods that are descriptive or describe the exact characteristics of a social phenomenon, both individuals, groups, and certain social conditions. The results showed that by carrying out the ceremonies and rituals of the Ngaruwat Bumi, the Banceuy indigenous people could maintain and preserve their environment. This requires efforts and support from all walks of life in maintaining the existence of these indigenous peoples so that their existence remains protected from the swift currents of modernization that continue to develop.

Keywords: traditional ceremonies; environmental conservation; traditional cultural values 


\section{Pendahuluan}

Merebaknya isu berkaitan dengan permasalahan kerusakan lingkungan hidup menjadi pembahasan di dunia yang muncul ke permukaan akhir-akhir ini karena permasalahan yang ditimbulkan akan berdampak luas dalam kehidupan manusia. Penyebab munculnya kasus lingkungan hidup ini memang sulit untuk ditelusuri, karena perkembangan teknologi dan moderinasasi sangat berperan penting dalam menunjang kehidupan manusia untuk memenuhi berbagai macam kebutuhannya.

Perkembangan teknologi yang semakin memanjakan ini mengakibatkan dampak negatif bagi lingkungan, karena pemanfaatan secara masif dalam bentuk ekspolitasi sumber daya alam secara besar-besaran dengan memanfaatkan teknoogi yang cangih. Kualitas sumber daya alam semakin menurun dari tahun ke tahun akibat dari eksploitasi ini, sehingga dibalik itu semua, ada harga yang harus dibayar mahal akibat kerusakan alam yang ditimbulkan. Banyaknya kasus kerusakan lingkungan mengindikaiskan adanya kemerosotan dan ketidak pedulian perilaku manusia dalam pengelolaan lingkungan hidup dalam menjaga dan memelihara kelestariannya.

Salah satu daerah yang memiliki ciri khas kehidupan yang unik dalam mengelola sumber daya alamnya adalah masyarakat adat Banceuy yang terletak di desa Sanca Kabupaten Subang Jawa Barat.

Arus globalisasi tidak bisa dihindari dengan berubahnya beberapa aspek kehidupan secara fisik, namun mereka tidak merubah suatu hal yang mereka anggap abstrak yaitu sebagai nilai atau adat istiadat yang telah lama mereka miliki. Maka dengan adanya hal tersebut kampung adat Banceuy memiliki suatu pedoman hidup yang tercermin dalam sebuah slogan yaitu "Ngindung ka Waktu Ngula ka Jaman" yang artinya pada sisi lain mereka tidak menolak perubahan, tetapi disisi lain untuk nilai atau adat istiadat tetap tidak bisa diganggu gugat dan tetap dipertahankan.

Dalam kehidupan adat Banceuy, masyarakat masih mempertahankan kebiasaan-kebiasan dan tradisi warisan leluhur dalam menjaga kelestarian lingkungan tempat tingggalnya. Mereka beranggapan bahwa alam merupakan bagian dari hidup manusia yang tidak dapat dipisahkan oleh karena itu mereka merasa harus melestarikannya.

Keunikan yang dimiliki oleh masyarakat adat Banceuy antara lain: 1) memiliki tokoh adat yang mampu mengendalikan perilaku dan kepercayaan masyarakatnya, 2) masyarakat adat nya selalu menjaga nilai -nilai luhur dan melaksanakan tradisi upacara adat sebagai hubungan timbal balik antara manusia dengan lingkungan alamnya. Masyarakat adat Banceuy meyakini bahwa filosofi hidup telah mereka lakukan dengan melaksanakan upacara adat, salah satunya adalah upacara ngaruat bumi juga di sebut hajat hajat bumi, yakni upacara yang dilaksanakan terkait dengan rasa syukur karena telah melaksanakan panen, terutama panen padi.

Sebagai ungkapan rasa syukur kepada sang pencipta karena keberhasilannya dalam menikmati hasil bumi berupa 
panen padi, maka masyarakat adat Banceuy selalu melaksanakan upacara ngaruwat bumi yang rutin dilaksanakan setiap tahun, dan mereka percaya dengan melaksanakan upacara ngaruwat bumi, maka akan terhindar dari segala bentuk bencana yang akan menimpa kampung mereka.

Rangkaian upacara sebelum melaksanakan upacara ngaruat bumi didahului oleh upacara hajat solokan, mapag cai, mitembeyan, netepkeun, ngayaran, hajar wawar, ngabangsar dan kariaan. Bagi masyarakat adat Banceuy, padi sifatnya sakral sehingga untuk memperolehnya diperlukan proses yang dianggap suci. Masalah dalam penelitian ini dibatasi pada upacara adat ngaruwat bumi sebagai kajian nilai budaya masyarakat adat Banceuy dalam melestarikan lingkungan.

Agar penelitian ini tepat sasaran, diperlukan batasan masalah yang dinyatakan dalam bentuk pertanyaan sebagai berikut: a). Apa yang menjadi latar belakang nilai-nilai pelaksanaan upacara adat? b). Hubungan upacara adat dengan pelestarian lingkungan, c). Adakah hubungan antara ritual dengan nilai budaya masyarakat dalam pelestarian alam?

Tujuan yang ingin dicapai dalam penelitian ini adalah: untuk mengetahui: a) latar belakang dilaksanakannya upacara adat, b) gambaran menyeluruh pelaksanaan upacara adat, c) identifikasi nilai budaya yang terdapat dalam upacara adat dalam melestarikan lingkungan

Penelitian ini diharapkan dapat mendokumentasikan nilai budaya masyarakat dalam mendukung upacara adat sehingga hasilnya ikut menambah kekayaan nilai-nilai budaya di masyarakat secara keseluruhan.

\section{Metode}

Metode yang digunakan dalam penelitian ini adalah metode historis dengan pendekatan interdisipliner yang menggunakan bantuan ilmu sosial lainnya seperti disiplin ilmu Sosiologi dan Antropologi. Untuk pengumpulan data yaitu menggunakan teknik wawancara, studi kepustakaan, dan studi dokumentasi. Metode historis adalah proses menguji dan menganalisis secara kritis rekaman dan peninggalan masa lampau dan menuliskan hasilnya berdasarkan fakta yang telah diperoleh yang disebut historiografi (Gottschalk, 1986, hlm.32). Penelitian dilakukan di Kampung Banceuy Desa Sanca, Kecamatan Jalancagak Kabupaten Subang. Lokasi penelitian difokuskan pada satu lokasi untuk mendapatkan data yang fokus. Pemilihan lokasi ditentukan atas pertimbangan biaya, waktu, dan akses penelitian. Subjek penelitian adalah masyarakat kampung adat Banceuy, Kecamatan Jalancagak Kabupaten Subang. Teknik Pengumpulan Data. a. Wawancara. Wawancara dilakukan secara mendalam dan bersifat terbuka kepada narasumber dari kalangan masyarakat dan tokoh adat Banceuy. Wawancara menggunakan jenis pertanyaan substantif untuk mendapatkan data secara langsung dari masyarakat dan pelaku setiap peristiwa yang merupakan orang-orang yang benar-benar mengalami atau terlibat langsung dalam peristiwa 
tersebut, seperti institusi pemerintahan atau masyarakat adat Banceuy itu sendiri. b. Observasi, metode pengumpulan data yang kompleks karena melibatkan berbagai faktor dalam pelaksanaannya. Metode pengumpulan data observasi tidak hanya mengukur sikap dari responden, namun juga dapat digunakan untuk merekam berbagai fenomena yang terjadi. Teknik pengumpulan data observasi cocok digunakan untuk penelitian yang bertujuan untuk mempelajari perilaku manusia, proses kerja, dan gejala-gejala alam. c. Studi pustaka Mengkaji sumbersumber tertulis yang relevan dengan penelitian yang didapatkan dari berbagai sumber antara lain dari perpustakaan. Berbagai penelitian mengenai masyarakat adat ini telah dilakukan Kehidupan Masyarakat Adat Kampung Banceuy: Kebertahanan Adat Istiadat Menghadapi Perubahan Sosial budaya (Selma Nurul Afifah dan Syarif Moeis 2017), Perempuan Dan Kearifan Lokal: Performativitas Perempuan Dalam Ritual Adat Sunda, (Jajang A Rohman, 2019), Kajian Nilai Budaya Tentang Mitos Dan Pelestariaan Lingkungan Pada Masyarakat Banceuy Kabupaten Subang (Endang Supriatna, 2011) mendapatkan temuan yang serupa bahwa dengan melaksanakan upacara adat dapat mempertahankan dan kelestarian lingkungan.

\section{Hasil dan Pembahasan}

\section{Sekilas kampung adat Banceuy}

Kampung adat Banceuy termasuk ke dalam wilayah Administratif desa Sanca Kecamatan Jalan cagak Kabupaten Subang
Jawa Barat. Letak geografisnya berada pada ketinggian 770 meter di atas permukaan laut dengan luas wilayah mencapai $157 \mathrm{Ha}$, yang terdiri dari 47 hektar dari luas tersebut adalah hutan, 78 hektar berupa sawah, 20 hektar kebun, yang merupakan sumber daya alamnya dan 12 hektar digunakan sebagai lahan hunian penduduk. Begitu luasnya area sawah dan hutan yang dimiliki oleh kampung adat Banceuy dibandingkan dengan luas pemukiman penduduk, menandakan bahwa masyarakat adat disana masih menggantungkan hidupnya pada sumber kekayaan alam, khususnya dari hasil pertanian. Pola perkampungan linier pada keadaan alam di kampung adat Banceuy dibuktikan dengan dibangunnya jalan desa, rumah rumah penduduk, sarana peribadatan, sarana jual beli, dan sarana oleh raga. Namun dalam bentuk fisik bangunan ini, kampung adat banceuy tidak memiliki kekhasan tersendiri. Namun dalam pola membangun rumah, ada aturan tersendiri dalam penerapannya, diantaranya letak pintu masuk, letak goah tempat menyimpan cadangan makanan, letak kamar tidur, karena dalam masyarakat sunda, khususnya adat Banceuy, posisi dalam menentukan letak ruangan-ruangan tersebut memiliki makna tersendiri menurut perhitungan dari mitos yang sudah dilaksankan dengan turun temurun (Suhamiharja, 1997:67). Tak jauh dari rumah penduduk, banyak terdapat saung lesung. Lesung ini digunakan penduduk sebagai alat penumbuk padi, sedangkan saung lesung sering digunakan penduduk sebagai tempat untuk melaksanakan musyawarah, 
pertemuan maupun sebagai tempat pelaksanaan upacara adat. Masyarakat adat Banceuy percaya, jika melanggar nilai-nilai yang sudah tertanam sejak jaman nenek moyang ini dilanggar maka sesuatu yang buruk akan terjadi dalam kehidupan mereka. Teguhnya memegang adat pada masyarakat Banceuy dalam menjaga nilai-nilai tradisi sangat mengikat bagi seluruh masyarakat adat Banceuy. Masyarakat adat Banceuy sendiri percaya, mana yang boleh dilakukan mana yang tidak boleh dilakukan. (Narwoko J. Dwi dan Bagong S. 2013:55).

Dalam masyarakat Banceuy menjaga hubungan erat dengan para leluhur merupakan suatu hal yang sangat penting karena menurut kepercayaan mereka, para leluhur inilah yang dahulu membuka kawasan ini menjadi kampung Banceuy. Sebagai bentuk penghormatan kepada para leluhur, maka masyarakat memformulasikan nya dalam bentuk upacara adat atau ritual-ritual adat yang dilaksanakan pada waktu-waktu tertentu.

\section{Pola perkampungan}

Nama kampung Banceuy dahulunya adalah kampung Negla, namun berubah menjadi Banceuy karena ada riwayat yang mengatakan bahwa pada waktu dulu kampung Negla kedatangan 7 keluarga yangmenetap dan tinggal di kamppung sana. Pada suatu hari kampung tersebut dilanda bencana alam berupa banjir disertai angin topan, sehingga rumahrumah warga kampung tersebut hancur, lalu secara perlahan mereka kembali membangun rumahnya, ke tujuh anggota keuarga ini lalu berdiskusi agar bencana alam serupa yang telah menimpa kampung mereka tidak terulang kembali. Lalu ketujuh naggota keluarga ini berdiskusi dengan mendtangkan paranormal, dan menurut terawangan para normal agar kampung tersebut terhindar dari bencana yakni ada hal yang harus dilakukan oleh masyarakat kampung tersebut, diantaranya: pertama, yang memimpin kampung tersebut harus merupakan keturunan dari Aki Ito, kedua masyarakat harus melaksanakan upacara ruwatan setiap habis panen sebagai wujud ungkapan rasa syukur kepada sang pencipta, dan ketiga nama kampung tersebut harus dirubah.

Menurut tradisi turun temurun yang disampaikan secara lisan oleh para orang tua, menjadikan perubahanperubahan pada masyarkat Banceuy itu sendiri khususnya perubahan pada kehdupan sosial dan budaya. Menurut Nanang Martono (2012:2) menyatakan: "studi perubahan sosial akan melibatkan dimensi ruang dan waktu. Dimensi ruang menunjukan pada wilayah terjadinya perubahan sosial serta kondisi yang melingkupinya. Dimensi waktu dalam studi perubahan meliputi konteks masa lalu (past), sekarang (present) dan masa depan (future). Perubahan yang terjadi dalam masyarakat Kampung Banceuy ini memiliki bentuk kausalitas (sebab-akibat) seperti yang diungkapkan"

Menurut Pudjiwati Sajogyo (1985:125) mengatakan bahwa "manusia sebagai makhluk yang berakal berupaya mencari sebab-sebab dari setiap kejadian. Dengan mengetahui sebabnya berarti memahami akar dan sumber akibat atau 
kejadian begitupun dengan adanya fenomena perubahan sosial atau budaya". Perubahan yang terjadi selanjutnya yakni perubahan yang terjadi pada masyarakat Banceuy itu sendiri berupa perubahan eksternal dan perubahan internal. Kehidupan masyarakat berubah seiring dengan perkembangan jaman. Perubahan eksternal yang terjadi pada masyarakat Banceuy yakni terlihat dari cara mereka mendirikan rumah, maupun bangunan lainnya seperti berdirinya sekolah, balai pertemuan warga tempat masyarakat, sesepuh dan tokoh adat berkumpul dan melaksanakan upacara adat. Perubahan besar yang terjadi adalah pada tahun 1999 kampung Banceuy dijadikan kampung adat dan dijadikan kampung wisata adat.

Selain faktor eksternal yang mempengaruhi kebiasaan masyaraat adat banceuy, terdapat pula faktor internal yakni bertambahnya jumlah penduduk, baik itu keturunan masyarakat banceuy itu sendiri maupun pendatang yang bermukim di kampung Banceuy, sehingga dengan heterogennya penduduk disana menjadikan perkembangan baru dalam teknologi dan peralatan yang digunakan. Adanya interaksi yang terjadi dengan masyarakat luar, ditambah lagi dengan masuknya aliran listrik di kampung tersebut pada tahun 1999 menjadikan masyarakat Banceuy banyak melakukan kontak dengan pihak luar.

Meningkatnya kesadaran masyarakat Banceuy akan pendidikan yang lebih tinggi menjadikan masyarakat Banceuy memberikan akses agar pembangunan sekolah-sekolah di kampung tersebut didirikan, baik itu pendidikan formal maupun informal. Menurut Endang Supriatna, (2010:17), menyatakan: "pada masa-masa sebelumnya, kendala dalam tingkat pendidikan masyarakat Banceuy adalah mereka melihat contoh tetangga yang berpendidikan tinggi, tetap kembali menjadi petani. Dalam padangan mereka untuk menjadi petani tidak perlu sekolah tinggi, yang membutuhkan biaya cukup besar bagi mereka."

Dengan adanya pandangan dari orang tuanya yang seperti itu mengakibatkan anak-anak di kampung Bnaceuy lebih memilih menjadi petani atau beternak, karena pada dasarnya belajar menjadi petani atau peternak tidak memerlukan biaya yang mahal. Namun perkembangan selanjutnya yang terjadi pada masyarakat Banceuy menganggap pendidikan formal juga penting bagi anak-anak mereka.

Namun perubahan yang melanda masyarakat kampung adat banceuy tidak menjadikan lunturnya nilai-nilai adat yang selama ini mengikat masyarakat. Mereka tidak meninggalkan kebiasaan dan tradisi yang selama ini diwariskan oleh para leluhurnya dengan tetap mengadakan upacara adat tertentu pada waktu yang telah ditentukan. (Darsih, wawancara tanggal 14 Maret 2018). Keyakinan masyarakat adat Banceuy dalam melestarikan adat dan budaya didukung oleh para sesepuh dan tokoh adat agar mereka tetap melestarikan apapun yang dilakukan oleh leluhur mereka. Hingga sekarang masyarakat Banceuy masih memperlihatkan sikap tradisionalnya. Sikap masyarakat dan tokoh adat ini 
mampu menghambat perubahanperubahan sosial dan budaya yang mulai masuk ke dalam masyarakat Banceuy. Hal ini diperlihatkan oleh tokoh masyarakat yang selalu berperan dalam mempengaruhi nilai-nilai yang mengikat dalam kehidupan sehari-hari seperti tetap melaksanakan gotong royong, dan gaya hidup mereka yang tetap melestarikan tradisi melaksanakan upacara adat di dalam menjalani kehidupannya. Bagi masyarakat adat, alam merupakan bagian dari kehidupan mereka. Apapun yang menyangkut kehidupan mereka selalu mengadakan berbagai macam ritual dengan melaksanakan upacara adat. Adat istiadat ini merupakan bagian dari kehidupan masyarakat banceuy sebagai bentuk rasa syukur terhadap sang pencipta.

Menurut E.B Taylor dalam buku Soekanto, (1995:188), mengatakan bahwa: " kebudayaan sebagai berikut: Kebudayaan adalah kompleks yang mencangkup pengetahuan, kepercayaan, kesenian, moral, hukum, adat istiadat dan lain kemampuan-kemampuan serta kebiasaan-kebiasaan yang didapatkan oleh manusia sebagai anggota masyarakat". Upacara adat yang biasa dilakukan oleh masyarakat banceuy biasanya selalu berkaitan dengan rasa syukur karena alam sudah memberikan nikmat berupa hasil panen, seperti upacara mapag cai, upacara hajat solokan, ngaruwat bumi, upacara netepkeun dan upacara nganyaran. Kebiasan dan tradisi ini mengikat masyarakat adat dan tidak boleh ditinggalkan, apabila tidak dilaksanakan maka akan terjadi suatu musibah yang akan menimpa kampung mereka. J. Dwi Narwoko dan Bagong S. (2013:55) mengatakan bahwa: “ dikarenakan adat istiadat (custom) merupakan bagian dari kontrol sosial, anggota masyarakat yang melanggar adat-istiadat, akan menderita sanksi yang keras dan kadang-kadang secara tidak langsung diperlakukan."

Upacara rutin yang selalu diadakan oleh masyarakat adat setiap tahun yakni upacara ngaruwat bumi.

Larangan-larangan yang biasa dilaksanakan oleh masyarakat Banceuy diantaranya dilarang menumbuk padi pada hari senin, selasa, jumat, dan tanggal 14 setiap bulan hijriyah, larangan ini dinamakan larangan Nyai Pohaci. Dalam membangun rumah pun tidak sembarangan, contohnya pintu menghadap selatan atau utara. Masyarakat Banceuy mematuhi aturan ini karena takut bencana akan akan diberikan oleh leluhur menimpa mereka. (Maryati, wawancara 14 Maret 2018).

Dalam sejarah masyarakat Banceuy, pernah mereka melanggar ritual upacara adat, yakni tidak melaksanakan pemotongan kerbau sebagai tumbal ketika melaksanakan upacara ngaruwat bumi, akibatnya, banyak ternak warga yang mati secara tiba-tiba, sehingga masyarakat beranggapan bahwa leluhur mereka marah karena tidak diberikan tumbal, juga hujan yang sangat besar terjadi ketika upacara adat heleran dilakukan tidak menggunakan kuda kososng (Mimin, wawancara tanggal 4 Mei 2018).

Masyarakat banceuy menyadari bahwa tidak ada sanksi hukum apabila tidak melaksanakan upacara adat ini, namun 
mereka akan merasakan sendiri dampaknya apabila upacara adat ini tidak dilaksanakan, yakni berupa bencana yang akan menimpa mereka. Adanya sanksi alam inilah yang tertanam dalam masyarakat Banceuy sehingga mereka selalu berusaha untuk mempertahankan dan melestarikan tradisi yang sudah berlangsung turun temurun tersebut. mereka selalu membiasakan diri melaksanakan upacara adat dengan baik sesuai dengan tradisi leluhurnya. (Opay, wawancara tanggal 5 Mei 2018).

Slogan masyarakat Banceuy "Ngindung ka Waktu Ngula ka jaman" selalu dijadikan pedoman oleh masyarkat banceuy, walaupun banyak perubahan sosial dan budaya yang masuk ke dalam lingkungan masyarakat. Masyarakat disana selalu saling mengingatkan agar selalu melaksanakan berbagai upacara adat apabila telah mengalami masa masa tertentu agar tidak terjadi bencana yang akan menimpa kampung mereka. Terkadang leluhur mereka datang melalui mimpi untuk mengingatkan agar mereka selalu melakukan ritual upacara adat. (Cucu, wawancara tanggal 5 Mei 2018).

Peran sesepuh adat dalam mempertahankan tradisi adat ini biasanya selalu disampaikan dalam pertemuanpertemuan yang rutin dilaksanakan melalui pengajian setiam kamis malam. Petuah ini disampaikan agar para generasi muda memahami pentingnya melaksanakan tradisi yang selama iniberlaku di kampung banceuy adalah sebagai wujud rasa syukur kepada sang maha pencipta. (Totoh, wawancara tanggal 5 Mei 2018).
Selain usaha ini, mulai tahun 2008 masyarakat banceuy meningkatkan perannya melalui pendidikan dengan memasukan nilai-nilai adat pada jenjang pndidikan dasar, karena masyarakat banceuy percaya, menumbuhkan rasa cinta terhadap adat dan tradisi ini harus dimulai sejak dini kepada anak-anak mereka. Selain melalui pendidikan formal, kebiasaan menanamkan tradisi ini dilakukan ketika memperingati hari-hari besar dan hari kemerdekaan, mereka akan diajarkan pelatihan-pelatihan mengenai kesenian tradisional yang menajdi ciri khas masyarakat Banceuy, contohnya memainkan alat musik cemplungan, agar sejak kanak-kanak sudah tertanam dan memiliki rasa seni leluhurnya. (Sumardi, wawancara tanggal 26 Mei 2018). Dari upaya-upaya yang dilakukan ini, masyarakat Banceuy selalu berusaha untuk mempertahankan dan melestarikan adat istiadat leluhur pendiri kampung tersebut.

Masyarakat Banceuy meyakini ,bahwa konsep hidup terdiri dari empat unsur, yakni bumi, geni, angin, dan air. Gebungan ke empat unsur inilah yang membentuk sifat manusia. Selain ke empat unsur tadi terdapat pula empat unsur yang mempengaruhi sifat manusia, yakni, jiwa setan. Jiwa hewan, jiwa pohon, dan jiwa manusia. Ketiga unsur selain unsur jiwa manusia merupakan unsur penganggu bagi manusia yang mengarahkan pada arah kesesatan, dan hanya satu unsur yang membawa pada arah kebaikan, yakni unsur masnuia. Untuk menghindari godaan dalam menjalani kehidupan manusia maka jiwa 
manusia harus diperkuat dengan mengingat dan menyadari kodratnya sebagai manusia yang mampu hidup selaras dengan alam dan mampu menghalau nafsu-nafsu yang negatif.

Masyarakat Banceuy mengenal konsep kematian adalah lepasnya roh dari badan. Meraka mempercayai bahwa selama 40 hari setelah kematian roh orang yang meninggal masih ada di sekitar mereka, untuk itu keluarganya harus mengadakan sesajen dan tahlil untuk mendoakan sanak saudara yang meninggal tersebut. setelah 40 hari roh ini akan di jemput oleh leluhurnya yang sudah lebih dahulu meninggal, lalu roh-roh mereka dipercaya kumpul kembali sampai hari kiamat tiba. Masyarakat Banceuy mempercayai bahwa selama roh ini menunggu hari kiamat tiba, roh - roh leluhur tersebut akan mengawasi sanak saudaranya yang masih hidup, bahkan dengan ritual khusus roh ini bisa dipanggil tau diundang (dicaluk).

Masyarakat Banceuy juga mempercayai bahwa roh-roh leluhur ini akan dibebaskan mengunjungi keluarganya pada bulan ramadhan, sehingga sehari sebelum ramadhan tiba biasanya mereka akan mengadakan upacara mapag, yakni menyambut kedatangan roh-roh ini dengan menyediakan sesajen dan pada akhir bulan ramadhan juga akan kembali menyediakan sesajen sebagai bekal untuk para roh leluhur kembali ke alam ghaib (mekelan).

Kepercayan-kepercayaan tersebut melahirkan berbagai macam ritual-ritual upacara tradisional yang berkaitan dengan aktifitas pertanian berupa rasa syukur karena hasil panen yang didapatkan. Upacara ini antara lain:

a). Upacara mapag cai, ritual ini dilakukan untuk menyambut datangnya aliran air yang berasal dari sungai Cipadaringn yang melewati kampung tersebut. Pelaksanaan ritual dilakukan di laksanakan biasanya pada bulan ke sepuluh karena bertepatan dengan mengalirnya air sungai ke persawahan penduduk di sekitar kampung Banceuy. Ritul ini dilaksanakan karena mereka menganggap air merupakan kebutuhan vital bagi kehidupan sehari-hari.

b). Upacara hajat solokan, upacara ini dilakukan untuk meminta berkah kepada sang pencipta, dan karuhun penghuni sungai (solokan) agar aliran air selalu mengalir dengan lancar. Pelaksanaan ritual ini biasanya dilakukan di dua tempat, yakni di sungai eyang Ito dan sungai cipadaringn. Upacara dilaksanakan dengan menyembelih dua ekor domba sebagai persembahan kepada karuhun. Darah hasil sembelihan hewan ini akan dialirkan melalui sungai yang mengairi sawah warga, sehingga pemilik sawahlah yang secara patunngan akan mengeluarkan biaya untuk melaksanakan upacara tersebut.

c). Upacara ngaruwat bumi, biasanya dilaksanakan setelah masyarkat panaen padi sebagai bentuk rasa syukur kepada sang pencipta. Selain itu upacara ini ditujukan agar pada panen yang akan datang diberikan hasil penen yang meningkat dan juga kesuburan lahan.

d). Upacara netepkeun, yaitu ritual upacara untuk menyimpa beras pada 
tempat yang dianggap suci oleh masyarakat banceuy di dalam goah.

e). Upacara nganyaran, ritual ini dilakukan ketika padi pertama kali dikeluarkan dari goah sebagai tempat penyimpanannya.

\section{Sistem kemasyarakatan pada masyarakat Banceuy}

Telah dibahas sebelumnya, bahwa masyarakat banceuy merupakan masyarakat adat yang dicirikan dengan adanya tokoh masyarakat yang dianggap sebagai sesepuh dan dijadikan panutan oleh masyarakatnya. Tokoh atau panutan ini biasanya dipanggil abah, dan menepati posisi di masyarakat. Masyarakat Banceuy sangat menghormati sesepuh ini, segala kegiatan ritual upacara selalu melibatkan abah dalam pelaksanaannya. Abah juga yang akan memutuskan perkara jika terjadi perselisihan diantara anggota masyarakat adat.

Ketua adat dalam masyarakat Bnaceuy harus seorang laki-laki yang dibantu oleh anggota masyarakat lain yang dipercaya sebagai pinesepuh, atau biasanya oleh masyarakat banceuy di panggil "Aki". Aki ini bertugas membantu abah ketika melaksanakan ritual upacara adat.

Jabatan sesepuh ini bisa diwariskan kepada keturunan atau anak laki-laki abah, apabila abah tidak memiliki anak laki-laki maka jabatan ketua akan dipih dari anak laki-laki dari pinisepuh atau anak laki-laki dari pembantu sesepuh adat, namun syaratnya, calon pengganti ini sudah mendapatkan wangsit dari karuhun atau leluhurnya, dan kemudian abah akan memberikan jabatan ketua adat kepada penerus yang sudah menerima wangsit sesuai dengan petunjuk yang dia dapatkan dari leluhur atau karuhunnya.

Dalam struktur masyarakat Banceuy, pinisepuh pertama akan bertugas memimpin upacara adat ngalawar, selanjutnya pinisepuh yang kedua mempunyai tugas sebagai mediator antara masyarakat dan Abah, tugas pinisepuh yang ketiga adalah mendampigi Abah dalam melaksanakan kegiatan upacara adat, serta mewakili abah bila berhalangan.

Bila dilihat dari paparan kedudukan strata diatas, maka sesepuh/abah menduduki posisi tertinggi, selanjutnya pinisepuh dan juru kunci makam keramat, dan terakhir adalah masyarakat. Jejang kedudukan diatas merupakan bentuk penghormatan kepada sesepuh oleh masyarakat. Dalam strata kedudukan masyarakat adat Banceuy tidak mengenal kekayaan seseorang untuk di hormati. Masyarkat Banceuy juga menghormati masyarakat yang berpendidikan tinggi serta yang memiliki jabatan tertentu di pemerintahan. Masyarakat Banceuy sangat menghormati kedudukan guru.

Dengan adanya lapisan-lapisan di masyarakat tidak menjadikan masyarakat Banceuy menjadi kaku, semuanya dalam pengawasan dari Abah yang dibantu pinisepuh dalam menjalankan kehidupan adatnya sehari-hari. Sesepuh adat selalu mengontrol kegiatan yang berhubungan dengan larangan dan kegiatan yang dilakukan masyarakat. Mereka juga mematuhi aturan-aturan yang dibuat oleh pemerintahan setempat agar kontrol sosial selalu terjaga. 
Nilai-nilai gotong royong, tolong menolong dan kerjasama selalu mewarnai aspek kehidupan di masyarakat Banceuy.

\section{Nilai Mitos dan Upacara Tradisional Masyarakat Banceuy}

Hampir semua kebudayaan suku-suku di Indonesia memiliki unsur budaya yang bersifat universal, yakni memiliki ciri khas dalam melaksanakan upacara adatnya. Budi Santoso (1990:7) mengatakan bahwa: "upacara tradisional adalah tingkah laku resmi yang dibakukan untuk peristiwa-peristiwa yang tidak ditujukan pada kegiatan teknis sehari-hari, tetapi mempunyai kaitan dengan kepercayaan akan adanya kekuatan di luar kemampuan manusia atau kekuatan supernatural, seperti roh nenek moyang pendiri desa, roh leluhur yang dianggap masih memberikan perlindungan kepada keturunannya, dan sebagainya."

Ciri khas yang terdapat pada masyarakat Banceuy adalah upacara Ngaruwat Bumi yang sudah dilaksanakan sejak ratusan tahun yang lalu. Walaupun upacara adat ini rutin dilaksanakan, namun kesakralannya selalu dirasakan oleh seluruh masyarakat Banceuy. Upcara ngaruwat bumi merupakan wujud syukur karena keberhasilan panen padi yang rutin dilaksanakan oleh masyarakat adat Banceuy, juga pengharapan agar panen berikutnya hasil yang didapatkan juga melimpah, juga sebagai bentuk penghormatan kepada leluhur mereka.dlam bahasa sunda, ruwat berarti merawat dan mengumpulkan hasil bumi oleh masyarakat.
Mayoritas masyarakat Banceuy adalah petani, sehingga upacara adat ngaruwat bumi selalu digelar setelah sebelumnya dilaksanakan rangkaian kegiatan upacara adat solokan, mapag cai, mitembeyen, netepkeun, nganyaran, hajar wawar, ngabangsar, dan kariaan.

Ritual upacara ngaruwat bumi merupakan upacara adat yang berhubungan dengan hasil penen padi. Bagi masyarakat banceuy padi merupakan sebuah benda yang suci, dan untuk mendapatkannya harus melalui ritual-ritual khusus, hal ini dilakukan sebagai bentuk penghormatan kepada dewi sri sebagai dewa dewi yang suci di aam khayangan.

Bentuk penghormatan warga terhadap padi dilakukan dengan melakukan ritual adat setelah panen dan pada masa akan dimulainya masa tanam berikutnya. Sebelum masa tanam berikutnya, rangkaian kegiatan diawali dengan upacara mapag cai, yakni dilakukan sebelum mengolah sawah dan sebelum benih disemai. Lalu menjelang menanam padi dilaksanakan kembali upacara mitembeyan. Sedangkan ritual untuk menyimpan padi pertama kali ke dalam goal adalah netepken. Ritual unuk mengeluarkan padi dari goah dinamakan nganyaran.

Upacara ngaruwat bumi di kampung Banceuy biasanya dilaksanakan diakhir bulan rayagung yang dipimpin oleh Abah sebagai sesepuh dan dibantu oleh kuncen atau juru kunci makam keramat. Pelaksanaan upacara ngaruwat bumi ini biasanya berlangsung selama sebulan, diawali dari perencanaan sampai dengan 
puncak acara berupa hiburan yang diisi dengan pentas seni. Menjelang acara puncak, pelaksanaan ritual diawali dengan potong padi, memberikan tumbal, dan menyiapkan sesajen, selamatan, arak-arakan dan terkahir berziarah ke makam leluhur.

Pagelaran gumbyung merupakan prosesi yang wajib dilaksanakan yang dilanjutkan dengan potong padi, numbal, dan selamatan. Namun untuk menghemat dana, biasanya ritual ini dilaksanakan tanpa adanya panggung hiburan dan pentas seni.

Rangkaian kegiatan yang dilakukan ini erat kaitannya dengan pertanian.

\section{Hubungan upacara adat dengan pelestarian lingkungan}

Mitos selalu berhubungan dengan keyakinan maupun kepercayaan di masyarakat. Menurut Usman Pely, (1991:13) mengatahkan bahwa: "ibadat sebagai bagian dari tingkah laku religius yang aktif dan bisa ditaati. Bentuknya, bisa berupa mantra, ucapan-ucapan formal tertentu, samadi, nyanyian, doa, pemujaan, puasa, tarian, mencuci, membaca, memakai pakaian khusus, menyembelih atau melakukan korban."

Dalam mengelola lingkungannya, masyarakat Banceuy masih mempercayai suatu kepercayaan hingga ujung-ujungnya akan berpengaruh dalam pola pikir dan tingkah laku dalam mengelola lingkungannya. Menurut kepercayaan masyarakat Banceuy, peradaban manusia diciptakan tidak terlepas dari kepercayaan dalam mengelola lingkungan hidupnya.
Mitos atau kepercayaan yang digunakan oleh masyarakat Banceuy secara tidak langsung memberikan pelajaran kepada manusia, bagaimana mengelola alam dengan baik agar terjaga kelestariannya. Banyak cerita ghaib maupun mitos mitos yang berkembang di masyarakat Banceuy yang sengaja dijadikan pedoman dalam menjalankan kehidupan dan menjaga kelestarian lingkungannya, benar tidaknya mitos tersebut menjadikan masyarakat Bnaceuy mempercayai bahwa secara tersirat mereka akan mengikuti perintah tersebut. Sebagai contoh, dalam menjaga kelestarian hutan dan gunung sebagai tempat yang kekuatan ghaib dan angker, sehingga sikap dan perilaku mereka berusaha menjaga kelestarian tempattempat tersebut dengan melestarikannya agar keberadaam mahluk ghaib tersebut tidak terusik. Saling menghormati dengan dengan menjaga alam dengan menghindari melakukan kegiatan-kegiatan di empat tersebut, kecuali jika melakukan ritual-ritual yang untuk menciptakan keseimbangan alam.

Melestarikan dan menjaga hewanhewan yang dianggap keramat di lingkungan sekitar juga dilakukan oleh masyarakat Banceuy. Hewan-hewan yang hidup merupakan penyeimbang ekosistem dalam kelestarian alam. Meurtut kepercayaan mereka, keberadaan ular sawah merupakanpenjelmaan dari dewi sri yang melambangkan kesuburan. Namun bila di tinjau daari segi ilmu biologi, keberadaan ular sawah akan membantu petani dalam memberantas tikus yang sering merusak tanaman padi, dan 
kotorannya sebagai pupuk alami yang dapat menyuburkan tanah.

Mitos mengenal hari baik dan larangan hari dalam masyarakat Banceuy juga menjadikan mereka memahami, kapan waktunya memulai bercocok tanam, dan kapan memanen hasil pertaniannya. Dengan mengenali hari baik untuk memulai bercocok tanam menjadikan unsur hara dalam tanah menjadi terjaga, sehingga petani dapat menghindari penggunaan pupuk buatan maupun pestisida dalam meningkatkan hasil panennya.

Masyarakat banceuy mengenal falsafah yang dikenal dengan pitutur luhur, yang artinya kata-kata bijaksana yang mengajarkan mereka akan nilai-nilai kehidupan, bagaimana seharusnya mereka bersikap dengan sesama mahluk hidup maupun dengan alam. Dalam falsafah ini mereka mengenal jika mereka rukun dengan sesama, maka kekuatan akan tumbuh, dan perpecahan akan menimbulkan kerusakan, artinya mereka harus selalu menjaga kerukunan dengan alam sekitarnya. Ajaran ini mengajarkan bahwa mereka harus hidup selaras dengan alam, tidak berbuat seenaknya, baik itu dengan alam maupun dengan sesama manusia.

\section{Ritual dan nilai budaya masyarakat dalam pelestarian alam}

Banyak ritual-ritual yang dilakukan oleh masyarakat Banceuy untuk berhubungan dengan alam. Pelaksanaan ritual ini sebagai bentuk kepercayaan bahwa selain manusia ada mahluk ghaib lain yang menempati lingkungan di sekitar tempat tinggal kita. Ritual yang dilaksanakan oleh masyarakat banceuy ini sebagai bentuk penghormatan kepada leluhur-leluhur penunggu gunung, hutan dan alam lain karena sudah melimpahkan banyak rejeki berupa hasil panen yang berlimpah. Menurut kepercayaan masyarakat Banceuy, keberadaan roh-roh leluhur tersebut mendatangkan berkah dan rejeki tersendiri bagi mereka, oleh karena itu sebagai wujud rasa terimakasih mereka mempersembahkan sesajen dalam bentuk ritual-ritual yang rutin dilaksanakan pada waktu-waktu tertentu. Malapetaka akan terjadi jika manusia merusak lingkungan.

Contohnya ketika para wisatawan mengunjungi tempat wisata curug bentang di kampung Banceuy, mereka akan meminta ijin dahulu kepada sesepuh penunggu tempat tersebut dengan melakukan ritual sebagai penghormatan kepada roh leluhur penunggu memohon keselamatan dan tidak menganggu para pengunjung tempat wisata, disini tersirat bahwa para wisatawan tidak diperkenankan untuk merusak maupun mengotori tempat tersebut.

\section{Kesimpulan}

Kita semua wajib memahami, bahwa nilai-nilai kearifan lokal memainkan peran dalam menerapkan nilai-nilai di masyarakat agar eksistensinya tetap bertahan seiring dengan derasnya arus modernisasi yang melanda seluruh wilayah.

Nilai-nilai kearifan lokal yang dimiliki oleh masyarakat Banceuy dalam menjaga kelestarian lingkungan harus disikapi dan 
dilindungi keberadaannya. Keberadaan masyarakat adat dengan kearifan lokalnya sesungguhnya terancam dengan arus perkembangan modernisasi, namun kita semua harus menyikapinya dengan bijak. Bijak disinibukan berarti menyetujui, namun dalam menghadapi dan menyikapi modernisasi ini masyarakat harus tetap berpegang teguh pada nilai-nilai yang diwariskan leluhur kepada kita.

Menjaga keseimbangan alam dan manusia merupakan nilai-nailai falsafah masyarakat Banceuy yang masih dipertahankan dalam kehidupan mereka sehaari-hari hingga kini. Mengimplementasikan nilai-nilai untuk membentuk sikap dalam mengelola lingkungan alam secara arif dan bijaksana dilakukan dengan kekuatan dalam mempertahankan tradisi melalui upacara adat yang selalu rutin dilaksanakan. Namun demikian mereka terus meningkatkan kualitas hidup mereka dengan selalu mempertahankan kehidupan tradisionalnya.

Dibutuhkan usaha dan dukungan dari semua lapisan masyarakat dalam mempertahankan keberadaan masyarakat adat ini agar keberadaannya tetap terlindungi dari derasnya arus modernisasi yang terus menerus berkembang. Usaha perlu dilakukan agar kearifan lokal masyarakat Banceuy tetap terjaga dan dan berkembang.

Diperlukan pula penanaman nilainilai yang didapatkan dari pembelajaran di lembaga pendidikan dengan mengintegrasikannya pada mata pelajaran tertentu, misalnya muatan lokal. Adapun untuk menanamkan nilai-nilai dalam memahami pentingnya keberadaan lingkungan dapat diberikan mata pelajaran khusus, misalnya mata pelajaran pendidikan lingkugan hidup.

Peran keluarga dalam menanamkan pendidikan dalam mengenalkan kearifan lokal perlu dilakukan pada anak-anak sejak usia dini dengan melibatkan mereka ketika pelaksanaan upacara adat yang dilakukan oleh masyarakat.

\section{Referensi}

Adeng, et.al. (1991). Upacara Tradisional Sedekah Bumi di Cibarusah-Bekasi. Bandung: Proyek terhadap Eksistensi Lembaga Adat Pemerintah Provinsi Daerah Tingkat I Jawa Barat.

Asshiddiqie, J. (2010). Konstitusi masyarakat desa (piagam tanggungjawab dan hak asasi warga desa) (online). Tersedia: (http://jimly.com/makalah/namafil e/176/KONSTITUSI_MASYARA KAT DESA.pdf)

Ekadjati, E. S. (1984). Masyarakat Sunda dan Kebudayaan. Jakarta: Girimukti Pusaka.

E. Supriatna dkk. (2010). Kajian nilai budaya tentang mitos dan pelestarian lingkungan pada masyarakat Banceuy Kabupaten Subang. Subang: Departemen Kebudayaan dan Pariwisata Balai Kajian Sejarah dan Nilai Tradisional Bandung.

Firth, R dkk. (Tanpa Tahun). Tjiri-tjiri dan alam hidup manusia suatu pengantar antropologi budaya. Bandung: Vorkink-Van Hoeve.

Gottschalk, L. (1986). Mengerti sejarah (terjemahan Nugroho Notosusanto). Jakarta: UI Press. 
Jurnal Pendidikan Kewarganegaraan

Vol. 5 No. 2 September 2018

Hidayah, Z. (2006). Metodologi Penelitian "Kepercayaan" Masyarakat. Jakarta: Makalah dalam Penataran Tenaga Teknis Pamong Budaya Sprirtual.

Ismaun. (2005). Pengantar sejarah sebagai ilmu dan wahana pendidikan. Bandung: Historia Utama Press Koentjaraningrat. (1970). Manusia dan kebudayaan di Indonesia. Jakarta: Penerbit Djambatan.

Koentjaraningrat. (2009). Pengantar ilmu antropologi. Jakarta: PT. Rineka Cipta

Lauer, R.H. (1993). Perpektif tentang perubahan sosial. Jakarta: Rineka Cipta.

Martono, N. (2012). Sosiologi perubahan sosial (perspektif klasik, modern, posmodern, dan poskolonial). Jakarta: Rajawali Pers.

Narwoko J. D., \& Bagong, S. (2013). Sosiologi teks pengantar dan terapan. Jakarta: Kencana.
Journal of Civics and Education Studies p-ISSN 2302-0865 | e-ISSN 2621-346X

Sajogyo, P. (1985). Sosiologi pembangunan. Jakarta: Fakultas Pasca Sarjana IKIP Jakarta.

Suhamiharja, A. S . (1997). Wujud arti dan fungsi puncak-puncak kebudayaan lama dan asli bagi masyarakat pendukungnya di jawa barat. Bandung: Departemen Pendidikan dan Kebudayaan Direktorat Jenderal Kebudayaan Direktorat Sejarah dan Nilai Tradisional Bagian Proyek Pengkajian dan Pembinaan NilaiNilai Budaya Jawa Barat 1995/1996.

Supriatna, N. (2013). Green history: belajar dari pengalaman historis hubungan manusia dengan alam. Jakarta: Kongres APPS. 
Jurnal Pendidikan Kewarganegaraan

Vol. 5 No. 2 September 2018
Journal of Civics and Education Studies p-ISSN 2302-0865 | e-ISSN 2621-346X

[ halaman ini sengaja dikosongkan ] 